\title{
PENGARUH KEPEMIMPINAN, MOTIVASI KERJA, KOMPETENSI TERHADAP KINERJA KARYAWAN STIKES SALEWANGANG MAROS
}

\author{
aSyafruddin, bSitti Nur Intang, 'Selvia \\ abc Stikes Salewangang Maros \\ syafruddin.salewangang@gmail.com
}

\begin{abstract}
This study aims to analyze the effect of leadership, work motivation, competence on the performance of employees of the Salewangang Maros High School of Health simultaneously and partially. The data processing analysis method used multiple regression analysis with the SPSS 25 program. The data collection technique used a questionnaire. In taking the sample in this study using the entire population of employees, amounting to 35 respondents. The results showed that $65.6 \%$ leadership, work motivation and competence affect the performance of employees at the Salewangang Maros College of Health Sciences. Leadership and competence partially have a positive and significant effect on employee performance, motivation has a negative and significant effect on employee performance, while simultaneously leadership, motivation and competence have a positive and significant effect on employee performance.
\end{abstract}

Keywords: Leadership, Work Motivation, Competence, Employee Performance.

\begin{abstract}
ABSTRAK
Penelitian ini bertujuan untuk menganalisis pengaruh kepemimpinan, motivasi kerja, kompetensi terhadap kinerja karyawan Sekolah Tinggi Kesehatan Salewangang Maros secara simultan dan parsial. Metode analisis pengolahan data menggunakan analisis regresi berganda dengan program SPSS 25. Teknik pengumpulan data menggunakan kuesioner. Dalam pengambilan sampel dalam penelitian ini menggunakan seluruh populasi karyawan yang berjumlah 35 responden. Hasil penelitian menunjukkan bahwa kepemimpinan, motivasi kerja dan kompetensi $65,6 \%$ berpengaruh terhadap kinerja pegawai pada Sekolah Tinggi IImu Kesehatan Salewangang Maros. Kepemimpinan dan kompetensi secara parsial berpengaruh positif dan signifikan terhadap kinerja karyawan, motivasi berpengaruh negatif dan signifikan terhadap kinerja karyawan, sedangkan secara simultan kepemimpinan, motivasi dan kompetensi berpengaruh positif dan signifikan terhadap kinerja karyawan.
\end{abstract}

Kata Kunci: Kepemimpinan, Motivasi Kerja, Kompetensi, Kinerja Karyawan.

\section{PENDAHULUAN}

Manajemen sebagai ilmu dan pengerjaan untuk mencapai tujuan melalui latihan orang lain menyiratkan bahwa tujuan dapat dicapai bila dilakukan oleh setidaknya satu individu. Sedangkan SDM sebagai bidang administrasi yang secara eksplisit mengkontemplasikan hubungan dan bagian dari manusia dalam suatu organisasi. Komponen dalam administrasi adalah tenaga kerja dalam suatu organisasi, sehingga dalam SDM pelaksana variabel yang harus diperhatikan adalah individu saja. Saat ini banyak organisasi memahami bahwa SDM adalah masalah utama organisasi karena melalui SDM lah berbagai aset di dalam organisasi dapat bekerja / dijalankan atau dieksekusi. Terlebih lagi, SDM dapat membuat 
produktivitas dan kecukupan organisasi. SDM yang layak membutuhkan administrator atau pelopor untuk melacak pendekatan yang paling ideal untuk melibatkan individu dalam asosiasi mereka dengan tujuan agar tujuan yang ideal dapat dicapai. (Rivai. Veithzal, Ramli. M, Mutis. Thoby, 2018)

Pendidikan dapat berupa suatu sistem yang terdiri dari berbagai macam bagian yang saling tertutup satu sama lain dalam menyatukan beberapa fungsinya. Oleh karena itu, setiap pihak harus mewaspadai setiap alternatif agar penerapan fungsinya berjalan lancar dan tujuan terstruktur dapat tercapai. Dalam menyelesaikan tugas sehari-hari mereka, staf harus mengikuti aturan kerja. Sehingga setiap organisasi pasti memiliki berbagai ketentuan yang harus dipatuhi oleh anggotanya, standar yang harus dipenuhi, dan ingin mendapat perhatian agar dapat meningkatkan standar kinerja pekerja dalam pekerjaannya.

Ada fenomena yang mulai muncul pada Lingkup Sekolah Tinggi IImu Kesehatan Salewangang Maros adalah pemahaman dan pengaplikasian struktur organisasi yang terbentuk dalam tata kelola dan tata laksana yang kepemimpinannya ditangani langsung oleh Ketua Stikes selaku Top Lederaship nampaknya mengalami beberapa permasalahan diantaranya :

1) Pemahaman birokrasi atau hirarki di pendidikan tinggi saat ini khususnya di Sekolah Tinggi IImu Kesehatan Salewangang Maros dalam arti birokrasi atau hirarki di semua lini belum maksimal terlaksana secara optimal dikarenakan pemahaman dan penafsiran dalam memimpin organisasi belum dipahami secara benar.

2) Pelayanan yang mengarah kepada pelayanan prima jauh dari pada yang diharapkan, karena kekuatan kekuasaan yang dominan muncul pada saat dibutuhkan pelayanan, yang pada akhirnya muncul lah pelayanan setengah hati.

3) Pergeseran Tupoksi organisasi harus dikelola dengan baik oleh Top Leadership, bila hal ini dibiarkan maka dampaknya akan membudaya dikalangan para pegawai Sekolah Tinggi Ilmu Kesehatan Salewangang Maros

Hal ini memiliki konsekuensi bahwa setiap pimpinan wajib memberikan perhatian yang serius dalam membina, menggerakkan, mengarahkan seluruh calon karyawan di lingkungannya agar volume dan beban kerja yang diarahkan pada tujuan dapat terwujud. Pimpinan perlu memberikan bimbingan yang serius kepada karyawan guna meningkatkan kinerja yang tinggi.

\section{TUJUAN PENELITIAN}

Menganalisis pengaruh kepemimpinan, motivasi kerja, kompetensi terhadap kinerja karyawan Sekolah Tinggi Kesehatan Salewangang Maros secara parsial dan simultan.

\section{Kinerja}

\section{TINJAUAN PUSTAKA}

Kinerja memiliki dua dimensi, dimensi pertama adalah efektivitas yang mengarah pada pencapaian target dari segi kualitas, kuantitas dan waktu. Kedua adalah efisiensi dalam hal membandingkan input dengan penggunaan aktualnya atau bagaimana pekerjaan dilakukan. (Baard et al., 2014) Sedangkan menurut (Sedarmayanti, 2011) kinerja adalah penjabaran kinerja yang artinya hasil kerja seorang pekerja, suatu proses manajemen atau suatu organisasi secara keseluruhan, dimana hasil pekerjaan tersebut harus menunjukkan bukti yang konkrit dan terukur (dibandingkan dengan standar yang telah ditetapkan sebelumnya). (Mangkunegara, 2016) Kinerja diukur dari pengakuan karyawan terhadap kualitas pekerjaan yang dilakukan di mana pegangan pekerjaan mendekati titik tanpa cacat. Sedangkan menurut (Stephen, 2006) indikator kinerja dapat diukur melalui, yaitu sebagai berikut : a. Kualitas (mutu) Kinerja dikur dari persepsi pegawai terhadap kualitas pekerjaan yang dihasilkan dimana proses hasil kerja mendekati titik kesempurnaan. b. Kuantitas (jumlah) Jumlah target yang diharapkan melebihi dari target yang telah ditetapkan, Jumlah target yang diantisipasi melebihi target yang telah ditetapkan sebelumnya, produksi yang dicapai 
akan datang dapat berada dalam kerangka siklus kegiatan yang telah diselesaikan. c. Ketepatan waktu suatu pekerjaan diberikan waktu untuk menyelesaikan pekerjaan tersebut dan tingkat aktivitas diselesaikan di awal waktu serta memaksimalkan waktu yang tersedia untuk aktivitas lainnya. d. Efektivitas Tingkat penggunaan sumber daya organisasi seperti energi, uang, teknologi, ditingkatkan dengan memaksimalkan hasil dalam penggunaan sumber daya. e. Efisiensi merupakan tingkatan kesesuaian pendapatan dan pengeluaran dengan menggunakan biaya serendah mungkin.

\section{Gaya kepemimpinan}

Kepemimpinan mencakup bagian yang sangat penting dalam aktivitas kerja, terutama yang terkait dengan gaya kepemimpinan transaksional. Kepemimpinan adalah seseorang yang memiliki spesialis untuk menurunkan tugas, memiliki kapasitas untuk mempengaruhi atau mempengaruhi orang lain (bawahan) melalui desain hubungan yang hebat untuk mewujudkan tujuan yang telah ditetapkan sebelumnya. (Amirullah, 2017)

Kepemimpinan transaksional adalah kepemimpinan yang membantu organisasi mencapai tujuan saat ini dengan lebih efisien, seperti dengan menghubungkan kinerja pekerjaan dengan penilaian penghargaan dan memastikan bahwa pekerja memiliki sumber daya yang dibutuhkan untuk menyelesaikan pekerjaan. Pemimpin transaksional menurut Bass (Stephen, 2015) Kepemimpinan juga dikemukakan oleh Yukl yang menurutnya merupakan cara untuk mempengaruhi orang lain dalam mengatur untuk mendapatkannya dan setuju tentang apa yang harus dilakukan dan bagaimana melakukannya, menghitung cara mendorong upaya individu atau kelompok untuk mencapai tujuan bersama. (Yukl, 2015).

\section{Motivasi Kerja}

Menurut (Siagian, 2018) Motivasi kerja merupakan tenaga penggerak yang menyebabkan seorang anggota organisasi mau dan mau mengerahkan kemampuannya untuk membentuk keterampilan dan ketrampilan personel serta waktu untuk melaksanakan berbagai kegiatan yang menjadi tanggung jawabnya dan memenuhi kewajibannya guna mencapai tujuan. mencapai tujuan dan sasaran organisasi yang telah ditentukan sebelumnya.

Motivasi sangat penting untuk meningkatkan kinerja, karena kinerja sangat bergantung pada aktualisasi pencapaian yang dicapai. Menurut (Hasibuan, 2017), Motivasi kerja karyawan dipengaruhi oleh kebutuhan berprestasi, afiliasi, kebutuhan kemampuan dan kebutuhan kekuasaan.

Teori ERG Alderfer (Existence, Relatedness, Growth) merupakan teori motivasi yang dikemukakan oleh Clayton P. Alderfer. Teori Alderfer menemukan 3 kebutuhan dasar manusia: (1). Existence Needs merupakan kebutuhan untuk dapat hidup sesuai dengan kebutuhan tingkat rendah Maslow, yang meliputi kebutuhan fisiologis dan kebutuhan keselamatan serta faktor higienitas Herzberg. (2). Kebutuhan Keterkaitan mencakup kebutuhan untuk berinteraksi dengan orang lain. Kebutuhan ini sesuai dengan kebutuhan afiliasi Maslow dan faktor kebersihan Herzberg. (3). Pertumbuhan Kebutuhan adalah kebutuhan yang mendorong seseorang untuk memiliki pengaruh yang kreatif dan produktif terhadap diri sendiri atau lingkungannya. Terwujudnya kebutuhan apresiasi dan realisasi diri Maslow serta faktor motivasi dari Herzberg. (Mangkunegara, 2011)

\section{Kompetensi}

Kompetensi merupakan kemampuan seseorang yang dilandasi oleh keterampilan, pengetahuan dan didukung oleh sikap kerja serta penerapannya dalam melaksanakan tugas dan pekerjaan di tempat kerja yang mengacu pada persyaratan kerja yang ditentukan. (Sutrisno. Edy, 2015). Kompetensi adalah kemampuan untuk melaksanakan tugas atau pekerjaan yang dilandasi oleh pengetahuan, keterampilan, dan didukung oleh sikap yang merupakan ciri individu.

Kompetensi memiliki lima ciri (Spencer dan Spencer) dalam (Wibowo, 2018). adapun ciri kompetensi yaitu: 1). Motif adalah sesuatu yang dipikirkan secara konsisten; 2). 
pengetahuan (knowledge) adalah informasi yang dimiliki seseorang untuk bidang tertentu; 3). Ciri atau ciri yang mempengaruhi cara seseorang menanggapi berbagai informasi dan situasi serta berperilaku dengan cara tertentu, yang ditunjukkan melalui rasa percaya diri, daya tahan, pengendalian diri, 4). Keterampilan adalah kemampuan untuk melaksanakan tugas-tugas tertentu lahir batin., dan 5). konsep diri adalah sikap dan nilai yang dimiliki seseorang. Sikap ini diukur melalui tes responden untuk menentukan nilai seseorang dalam melakukan sesuatu. Sehingga dapat disimpulkan bahwa berbicara tentang kompetensi berarti sejauh mana suatu instansi telah mendidik dan melatih karyawannya sehingga memiliki standar kompetensi yang dibutuhkan untuk menjalankan tugas dan tanggung jawabnya.

Kompetensi merupakan potensi yang dimiliki karyawan dalam menjalankan tugas pokok dan fungsinya, indikator kompetensi mengacu pada window theory yang dikemukakan oleh Donald 2007:1 dalam (Lusman, 2017) yaitu : pengetahuan (knowledge), keterampilan (skills), pengalaman (experience) dan sikap (attitudes).

\section{Penelitian Terdahulu}

(Azmi \& Serang, 2019). Judul Penelitian: Pengaruh Motivasi, Kompetensi dan Lingkungan Kerja terhadap Kinerja Karyawan. Hasil penelitian ini adalah: mendapatkan variabel motivasi, kompetensi dan lingkungan kerja berpengaruh positif dan signifikan secara simultan terhadap kinerja pegawai desa di Kecamatan Lalabata Kabupaten Soppeng. Secara parsial diketahui bahwa faktor kompetensi yang paling dominan berpengaruh signifikan terhadap kinerja pegawai kelurahan di Kecamatan Lalabata Kabupaten Soppeng.

(Mulyani, 2019) Judul penelitian : Pengaruh Kompetensi Karyawan, Penempatan Kerja, dan Pengembangan Karir terhadap Kinerja Karyawan. Hasil penelitian ini adalah: Berdasarkan uji parsial (uji t) terdapat pengaruh yang positif dan signifikan antara Kompetensi terhadap Kinerja Karyawan, dinyatakan dengan nilai t hitung lebih besar dari $t$ tabel.

(Bharata \& Putro, 2019). Judul Penelitiannya: Pengaruh Kepemimpinan, Budaya Organisasi dan Komunikasi terhadap Kinerja Karyawan. Hasil dari pada penelitian ini adalah: menunjukkan bahwa terdapat pengaruh yang positif dan signifikan terhadap kinerja seluruh pegawai high school yang berada di bawah naungan Yayasan Bani Saleh, baik secara langsung dan melalui komunikasi.

\section{Kerangka Penelitian}

Penelitian ini akan menguji pengaruh kepemimpinan, motivasi kerja dan kompetensi terhadap kinerja karyawan. Gambaran skema kerangka dalam penelitian ini dapat dikemukakan sebagai berikut:

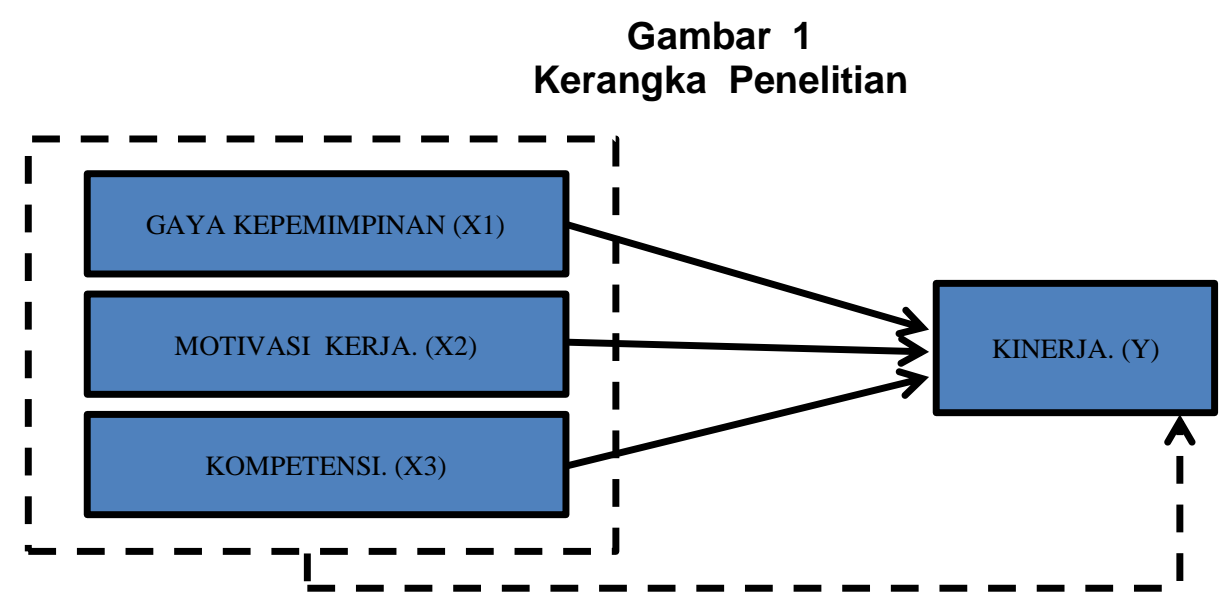

Berdasarkan kerangka konseptual di atas, maka dapat dibuat hipotesis sebagai berikut: 
H1 Kepemimpinan, berpengaruh terhadap kinerja pegawai Sekolah Tinggi Kesehatan Salewangang Maros.

H2 Motivasi Kerja, berpengaruh terhadap Kinerja Pegawai Sekolah Tinggi Kesehatan Salewangang Maros.

H3 Kompetensi, berpengaruh terhadap Kinerja Pegawai Sekolah Tinggi Kesehatan Salewangang Maros.

H4 Kepemimpinan, Motivasi Kerja, dan Kompetensi berpengaruh secara simultan terhadap Kinerja Pegawai Sekolah Tinggi Kesehatan Salewangang Maros.

\section{METODE PENELITIAN}

\section{Populasi dan Sampel}

Populasi adalah wilayah generalisasi yang terdiri dari: objek / subjek yang mempunyai kualitas dan karakteristik tertentu yang ditetapkan oleh peneliti untuk dipelajari dan kemudian ditarik kesimpulannya (Sugiono, 2015) Sedangkan menurut Arikunto (2012: 104) dalam (Retribusi et al., 2016) menyatakan apabila populasinya kurang dari 100 orang maka total sampel diambil secara keseluruhan, namun jika populasinya lebih besar dari 100 orang maka dapat diambil $10-15 \%$ atau $20-25 \%$ dari populasi tersebut. Dalam penelitian ini, seluruh karyawan Sekolah Tinggi Ilmu Kesehatan Salewangang Maros berjumlah 35 responden.

\section{Pengukuran dan Definisi Operasional}

Data yang akan digunakan dalam penelitian ini adalah data primer dan data sekunder. Data primer diperoleh peneliti dengan cara observasi, angket dan dokumentasi. Data yang terkumpul dari kuesioner akan diberi skor dengan skala likert 1-5 sebagai berikut: mulai dari Sangat Setuju (SS) hingga Sangat Tidak Setuju (STS)

Definisi operasional dari variabel penelitian ini adalah:

1. Kepemimpinan adalah membantu organisasi mencapai tujuannya saat ini dengan lebih realistis, indikatornya mengacu pada teori hasil dari Bass dalam (Stephen, 2015) antara lain: Contingent reward, Management by exception (aktif), Management by exception (passive), Laissez- faire.

2. Motivasi merupakan salah satu bentuk semangat individu yang datang dari dalam dan luar diri untuk bekerja secara maksimal setelah kebutuhan yang diinginkan terpenuhi. Indikator motivasi mengacu pada teori hasil Clayton Alderfer. dalam (Mangkunegara, 2011) yaitu : Existence Needs, Relatedness Needs, Growth Needs.

3. Kompetensi merupakan potensi yang dimiliki oleh karyawan dalam menjalankan tugas pokok dan fungsinya, indikator kompetensi mengacu pada window theory yang dikemukakan oleh (Donald 2007:1) dalam (Lusman, 2017) yaitu : pengetahuan, keterampilan, pengalaman dan sikap.

4. Kinerja berarti perbandingan antara hasil yang dicapai (keluaran) dengan keseluruhan sumber daya yang digunakan (masukan), indikator kinerja pegawai mengacu pada teori hasil dari (Stephen, 2006) yaitu a. Kualitas / mutu. b. Kuantitas / jumlah. c. Ketepatan waktu Pekerjaan. d. Efektivitas.

e. Efisiensi.

\section{Metode Analisis Data}

Pemeriksaan informasi dalam penelitian ini dibagi menjadi tiga tahap. Untuk mulai dengan, pengujian kualitas data, pengujian dari model dari penelitian dan pengaturan ketiga adalah pengujian hipotesis, menggunakan program SPSS 25.

\section{Analisis Regresi Berganda}

Analisis regresi digunakan untuk mengetahui pengaruh variabel independen : gaya kepemimpinan, motivasi kerja dan kompetensi, terhadap variabel dependen : kinerja karyawan dengan persamaan regresi sebagai berikut: 
$\mathbf{Y}=\mathbf{a}+\beta \cdot \mathbf{X} \mathbf{1}+\beta \cdot \mathbf{X} \mathbf{2}+\beta \cdot \mathbf{X} \mathbf{3}+\mathbf{e}$

dimana :

$Y=$ Kinerja Pegawai

$\mathrm{a}=$ Konstanta

X1 = Gaya Kepemimpinan

X2 = Motivasi Kerja

$\mathrm{X} 3=$ Kompetensi

$\mathrm{e}=$ Error

$\beta$ 1. $\beta$ 2. $\beta 3=$ Koefisien regresi

\section{Pengujian Kualitas data \\ Uji Validitas}

Uji validitas digunakan untuk mengukur valid tidaknya suatu kuesioner. Suatu kuesioner dikatakan valid jika pertanyaan-pertanyaan pada kuesioner tersebut mampu mengungkapkan sesuatu yang akan diukur oleh kuesioner tersebut. Kemudian validitas dapat mengukur apakah pertanyaan kuesioner yang telah dibuat benar-benar dapat mengukur apa yang ingin kita ukur. (Ghozali, 2018).

\section{Uji Reliabilitas}

Uji reliabilitas adalah alat untuk mengukur suatu kuesioner yang merupakan indikator dari variabel atau konstruk, suatu kuesioner dapat dikatakan reliabel atau memperoleh hasil yang sama pada percobaan yang sama, apabila jawaban responden terhadap pertanyaan dalam kuesioner konsisten atau stabil dari waktu ke waktu. (Ghozali, 2018)

\section{Pengujian Asumsi Klasik}

Sebelum pengujian regresi ini dilakukan, perlu dilakukan pengujian asumsi klasik. Uji asumsi klasik merupakan persyaratan statistik yang bertujuan untuk memberikan keyakinan bahwa model regresi yang digunakan dalam penelitian memiliki keakuratan estimasi, tidak bias dan konsisten. Model regresi harus memenuhi asumsi klasik yaitu normalitas, heteroskedastisitas dan multikolinearitas.

\section{Pengujian Hipotesis}

a. Digunakan Uji t untuk menguji tingkat pengaruh kritis antara variabel independen dan variabel dependen, ukuran tes ini ditentukan berdasarkan probabilitas. Jika tingkat signifikan yang digunakan adalah 5 persen, dengan kata lain jika kemungkinan $\mathrm{Ha}>0,05$ pada saat itu dinyatakan tidak signifikan dan jika kemungkinan $\mathrm{Ha}<0,05$ maka dinyatakan signifikan.

b. Digunakan Uji statistik F, untuk mengukur ketepatan terhadap fungsi regresi sampel dalam menafsirkan nilai yang sesungguhnya. Jika nilai signifikan $F<0,05$, maka model regresi sampel tersebut dapat digunakan untuk memprediksi variabel independen.

Semua variabel independen yang dimasukkan dalam model dengan menggunakan uji statistik $\mathrm{F}$ apakah juga memperlihatkan pengaruhnya secara bersama-sama terhadap variabel dependen. Signifikan uji statistik F sebesar : 0,05 (Ghozali, 2018).

\section{HASIL DAN PEMBAHASAN}

\section{Deskripsi Responden}

Responden dalam penelitian ini adalah 35 pegawai Sekolah Tinggi IImu Kesehatan Salewangang Maros. Sebagian besar responden adalah wanita dengan jumlah 26 orang atau sebesar: $74 \%$. Sementara responden laki-laki berjumlah 9 orang atau sebesar: $26 \%$. 
Usia pekerja Sekolah Tinggi Ilmu Kesehatan Salewangang Maros berada pada range antara 20 tahun dan kurang dari 50 tahun, sebagian besar responden berusia antara 23 - 35 tahun yaitu sebesar: 91\%. Sebagian besar pegawai memiliki berpendidikan Strata 2 (S2) tingkat akhir, yaitu berjumlah 24 responden atau sebesar: $68 \%$.

\section{Uji Kualitas Data \\ Uji Validitas dan Reliabilitas}

Tabel.1

Hasil Uji Validitas dan Reliabilitas

\begin{tabular}{|c|c|c|c|c|c|c|}
\hline \multirow[b]{2}{*}{ Variabel } & \multirow[b]{2}{*}{ Indikator } & \multicolumn{3}{|c|}{ Korelasi (r) } & \multicolumn{2}{|r|}{ Koefisien } \\
\hline & & $\mathrm{R}$ & Sig & Status & $\begin{array}{r}\text { Alpha } \\
\text { Cronbach }\end{array}$ & Status \\
\hline \multirow{4}{*}{ KEPEMIMPINAN (X1) } & $\mathrm{X} 1.1$ & .869 & .000 & Valid & \multirow{4}{*}{.944} & \multirow{4}{*}{ Reliabel } \\
\hline & $\mathrm{X} 1.2$ & .951 & .000 & Valid & & \\
\hline & $\mathrm{X} 1.3$ & .952 & .000 & Valid & & \\
\hline & $\mathrm{X} 1.4$ & .951 & .000 & Valid & & \\
\hline \multirow{5}{*}{ MOTIVASI KERJA (X2) } & $\mathrm{X} 2.1$ & .829 & .000 & Valid & \multirow{5}{*}{.854} & \multirow{5}{*}{ Reliabel } \\
\hline & $\mathrm{X} 2.2$ & .803 & .000 & Valid & & \\
\hline & $\mathrm{X} 2.3$ & .796 & .000 & Valid & & \\
\hline & $\mathrm{X} 2.4$ & .824 & .000 & Valid & & \\
\hline & $\mathrm{X} 2.5$ & .737 & .000 & Valid & & \\
\hline \multirow{4}{*}{ KOMPETENSI (X3) } & X3.1 & .836 & .000 & Valid & \multirow{4}{*}{.860} & \multirow{4}{*}{ Reliabel } \\
\hline & $\mathrm{X} 3.2$ & .815 & .000 & Valid & & \\
\hline & X3.3 & .892 & .000 & Valid & & \\
\hline & X3.4 & .815 & .000 & Valid & & \\
\hline \multirow{5}{*}{ KINERJA } & $\mathrm{Y} 1$ & .711 & .000 & Valid & \multirow{5}{*}{.800} & \multirow{5}{*}{ Reliabel } \\
\hline & $Y 2$ & .797 & .000 & Valid & & \\
\hline & Y3 & .806 & .000 & Valid & & \\
\hline & Y4 & .691 & .000 & Valid & & \\
\hline & Y5 & .748 & .000 & Valid & & \\
\hline asil Olah Data SPSS Ta & & & & & & \\
\hline
\end{tabular}

Pemeriksaan validitas selama penelitian ini menunjukkan bahwa setiap indikator variabel memiliki nilai korelasi> 0.3338 , artinya form yang digunakan memungkinkan untuk mengumpulkan informasi karena pertanyaan yang digunakan dalam form untuk mengukur variabel-variabel yang diteliti memiliki keakuratan yang valid.

Uji kualitas yang tak tergoyahkan digunakan untuk mengukur seberapa andal suatu instrumen digunakan dalam penelitian. Pengujian ini menggunakan koefisien alpha Cronbach. Instrumen dikatakan realibel (feasible) jika memiliki nilai Cronbach's alpha lebih dari 0.6 dan dianggap bermasalah jika Cronbach's alpha $<0.6$. Hasil uji realiabilitas menunjukkan bahwa insentif Cronbach's Alpha untuk setiap faktor adalah> 0.6, yang mengimplikasikan bahwa estimasi tersebut dapat memberikan hasil yang mantap jika digunakan untuk mengukur ulang subjek yang serupa.

\section{Uji Asumsi Klasik. \\ Uji Normalitas}

Pengujian normalitas dalam penelitian ini, menggunakan pemeriksaan dengan grafik $\mathrm{P}-\mathrm{P}$ Plot. Uji model regresi ini dilakukan untuk mengetahui apakah dalam penelitian variabel perancu berdistribusi normal. Konsekuensi dari Gambar 
Gambar 2.

Hasil Uji Normalitas

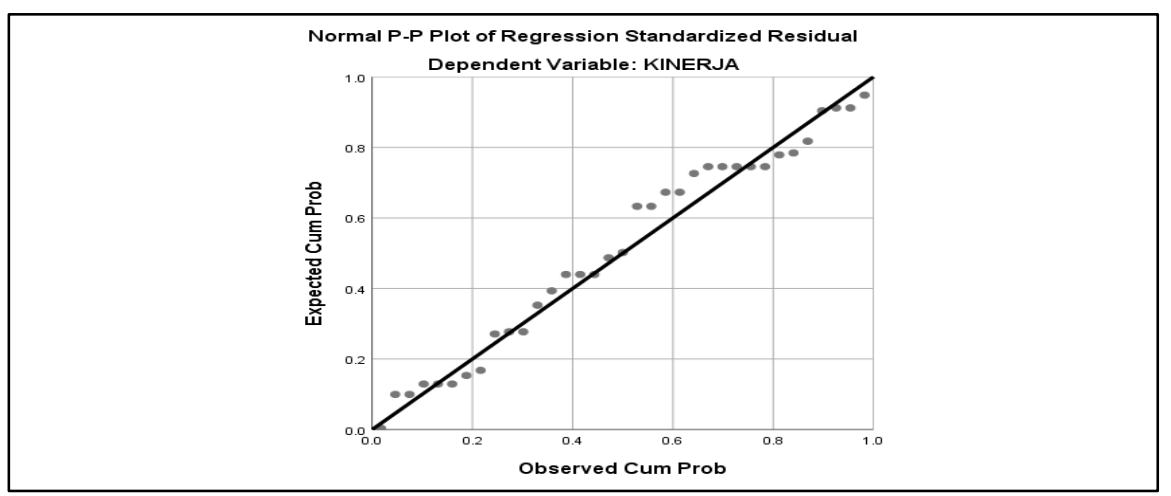

Pada Gambar 2 tersebut diatas menunjukkan tampilan bahwa grafik plot normal memperlihatkan adanya sebaran data titik-titik yang menyebar, dan searah dengan garis diagonal sehingga model regresi ini dapat disimpulkan : memenuhi asumsi normalitas.

\section{Uji Multikolinearitas.}

Dalam penelitian model regresi, wajar jika tidak ada hubungan antara faktor-faktor otonom tersebut. Pengujian multikolinearitas dalam penelitian ini menggunakan nilai toleransi dan inflasi varians (VIF). Diharapkan pada nilai toleransi tidak dibawah nilai 0.10 sedangkan nilai inflasi varians tidak melebihi nilai 10 . Hasil pengujian dalam penelitian ini dapat dilihat pada tabel 2 dibawah ini :

Tabel 2.

Uji Multikolinearitas

\begin{tabular}{|c|c|c|c|}
\hline \multirow{2}{*}{ Model } & & \multicolumn{2}{|c|}{ Collinearity, Statistics } \\
\hline & & Tolerance & VIF \\
\hline \multirow[t]{4}{*}{1} & (Constant) & & \\
\hline & Kepemimpinan & 0.996 & 1.004 \\
\hline & Motivasi Kerja & 0.988 & 1.012 \\
\hline & Kompetensi & 0.992 & 1.008 \\
\hline
\end{tabular}

$\because$ Hasil Olah Data SPSS Tahun 2020

Nilai toleransi dari hasil perhitungan pada tabel 2 menunjukkan bahwa variabel independen yang diteliti tidak satu pun yang memiliki nilai toleransi dibawah 0.10 dan nilai inflasi varians (VIF) memperlihatkan nilai dibawah 10. Dengan demikian dapat ditarik kesimpulan bahwa diantara variabel independen dalam model penelitian ini tidak terdapat multikolinearitas.

\section{Uji Heteroskedastisitas}

Grafik scatterplot digunakan dalam penelitian ini untuk menguji heteroskedastisitas. Dalam model regresi, uji multikolinearitas dilaksanakan untuk mengetahui ketidaksamaan 
varian dari residual dari satu pengamatan ke pengamatan yang lainnya. Dari hasil analisis SPSS.25 dapat dilihat pada Gambar 3 sebagai berikut :

Gambar 3.

\section{Hasil Uji Heteroskedastisitas}

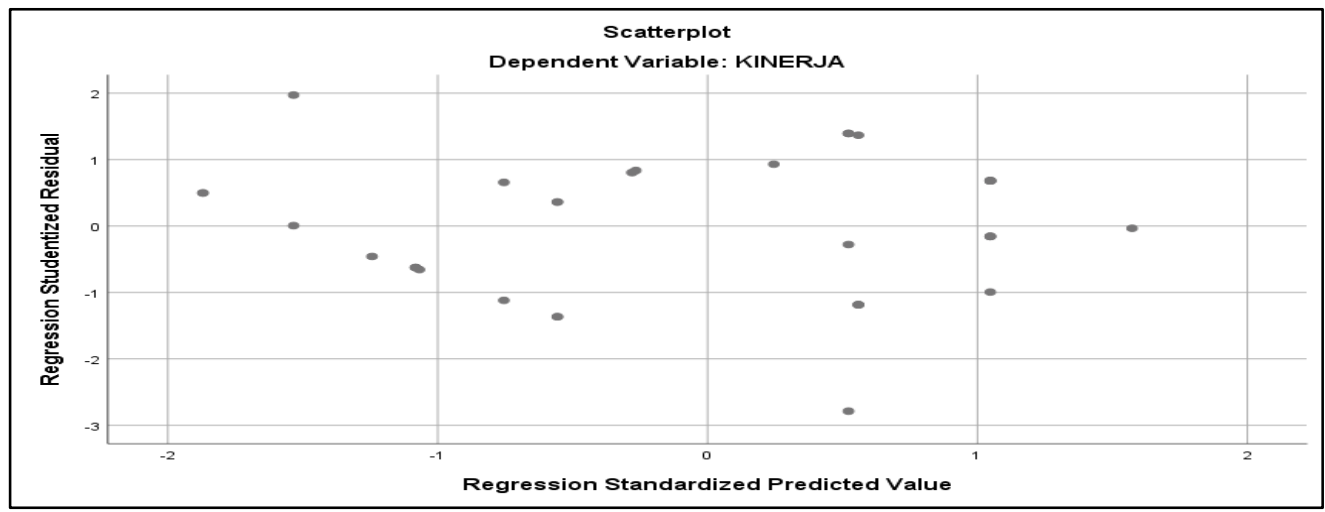

Hasil uji yang terlihat pada grafik scatterplot diatas menunjukkan bahwa sebaran semua data-data berada diatas dan bagian bawah nilai 0 yang berada pada sumbu $Y$, hal ini memperlihatkan bahwa pengujian memenuhi persyaratan uji asumsi klasik dan mengidentifikasikan tidak terjadinya heteroskedastisitas.

\section{Uji Hipotesis.}

Untuk mengetahui lebih mendalam dari pengaruh variabel independen dalam penelitian ini digunakan analisis regresi berganda, apakah memiliki pengaruh terhadap variabel dependen. Hasil penghitungan analisis data dengan menggunakan analisis statistik dan data diolah dengan SPSS. Hasil penghitungan uji t dapat dilihat pada tabel 3 dibawah ini :

Tabel 3

Koefisien Regresi, Uji T

\begin{tabular}{rr|r|r}
\hline Model & Standardized Coefficients & T & Sig. \\
& Beta & & \\
\hline Kepemimpinan & 0.588 & 5.572 & 0.000 \\
Motivasi Kerja & -0.438 & -4.130 & 0.000 \\
Kompetensi & 0.253 & 2.392 & 0.023 \\
\hline
\end{tabular}

Dari hasil perhitungan pada Tabel 3 maka dapat dijabarkan sebagai berikut:

Hasil statistik uji hipotesis untuk perhitungan variabel kepemimpinan memperoleh nilai t hitung sebesar 5.572 dengan tingkat ketidakpercayaan 0.05 dan nilai perhitungan dari t tabel dengan $\mathrm{df}=\mathrm{n}-\mathrm{k}-1=35-3-1=31$ diperoleh nilai tabel sebesar 2.040. Dari hasil uji statistik diperoleh $t$ hitung sebesar 5.572 lebih besar daripada t tabel 2.040. Hal ini menandakan bahwa $\mathrm{H} 1$ diterima dan kepemimpinan memberikan pengaruh terhadap kinerja pegawai sedangkan dari hasil perhitungan SPSS 25 variabel kepemimpinan 
memiliki tingkat signifikansi sebesar 0.000 lebih kecil dari 0.05 , hasil ini menunjukkan bahwa kepemimpinan (X1) terhadap kinerja pegawai $(Y)$ memiliki pengaruh yang signifikan.

Hasil statistik uji hipotesis untuk variabel motivasi kerja memperoleh nilai t hitung sebesar -4.130 dengan tingkat ketidakpercayaan 0.05 dan nilai perhitungan dari t tabel dengan $\mathrm{df}=\mathrm{n}-\mathrm{k}-1=35-3-1=31$ diperoleh nilai tabel sebesar -2.040 . Dari hasil uji statistik diperoleh t hitung sebesar -4.130 lebih besar daripada t tabel -2.040 . Hal ini menandakan bahwa $\mathrm{H} 2$ diterima dan motivasi kerja memberikan pengaruh terhadap kinerja pegawai sedangkan dari hasil perhitungan SPSS 25 variabel motivasi kerja memiliki tingkat signifikansi sebesar 0.000 lebih kecil dari 0.05 , hasil ini menunjukkan bahwa motivasi kerja (X2) terhadap kinerja pegawai (Y) memiliki pengaruh yang signifikan.

Hasil statistik uji hipotesis untuk perhitungan variabel kompetensi memperoleh nilai t hitung sebesar 2.392 dengan tingkat ketidakpercayaan 0.05 dan nilai perhitungan dari $t$ tabel dengan $\mathrm{df}=\mathrm{n}-\mathrm{k}-1=35-3-1=31$ diperoleh nilai tabel sebesar 2.040. Dari hasil uji statistik diperoleh $t$ hitung sebesar 2.392 lebih besar daripada $t$ tabel 2.040. Hal ini menandakan bahwa $\mathrm{H} 3$ diterima dan kompetensi memberikan pengaruh terhadap kinerja pegawai sedangkan dari hasil perhitungan SPSS 25 variabel kepemimpinan memiliki tingkat signifikansi sebesar 0.023 lebih kecil dari 0.05 , hasil ini menunjukkan bahwa kompetensi $(\mathrm{X} 3)$ terhadap kinerja pegawai $(\mathrm{Y})$ memiliki pengaruh yang signifikan.

Tabel 4.

Koefisien Regresi, Uji f

\begin{tabular}{rrrrrrrr}
\hline & \multicolumn{2}{c}{ Model ium of Squares } & & df & Mean Square & F & Sig. \\
\hline & Regression & 89.697 & 3 & 29.899 & 19.702 & $.000 \mathrm{~b}$ \\
1 & Residual & 47.045 & 31 & 1.518 & & \\
& Total & 136.743 & 34 & & & \\
\hline
\end{tabular}

Dari hasil perhitungan pada Tabel 4 maka dapat dijabarkan sebagai berikut:

Hasil uji statistik Kepemimpinan, motivasi kerja, kompetensi diperoleh nilai $\mathrm{f}$ hitung sebesar 19.702 dengan nilai $f$ tabel $=(k: n-k)=(3: 35-3)=(3: 32)$ diperoleh sebesar 2.92 . dari hasil uji tersebut menunjukkan bahwa $(\mathrm{H} 4)$ diterima, hal ini menandakan bahwa secara simultan : kepemimpinan, motivasi kerja, kompetensi berpengaruh terhadap kinerja pegawai pada sekolah tinggi ilmu kesehatan salewangang maros.

Dari hasil analisis data koefisien determinasi dengan SPSS diperoleh informasi bahwa nilai Adjusted $\mathrm{R}$ Square sebesar 0.656. Artinya, variabel kepemimpinan, motivasi kerja, kompetensi mempengaruhi 65.6 persen kinerja pegawai Sekolah Tinggi IImu Kesehatan Salewangang Maros dan 34.4 persen selebihnya dipengaruhi dari variabel lain diluar variabel penelitian ini.

Sedangkan variabel yang paling dominan dari hasil analisis koefisien standar menunjukkan bahwa variabel yang paling berpengaruh terhadap kinerja adalah kepemimpinan dengan nilai sebesar 0.588. disusul oleh kompetensi sebesar 0.253 dan motivasi kerja -0.438

\section{KESIMPULAN}


1. Hasil uji variabel kepemimpinan secara parsial menunjukkan pengaruh positif dan signifikan terhadap kinerja pegawai Sekolah Tinggi Ilmu Kesehatan Salewangang Maros.

2. Hasil uji variabel motivasi kerja secara parsial menunjukkan pengaruh negatif dan signifikan terhadap kinerja pegawai Sekolah Tinggi Ilmu Kesehatan Salewangang Maros.

3. Hasil uji variabel kompetensi secara parsial menunjukkan pengaruh positif dan signifikan terhadap kinerja pegawai Sekolah Tinggi llmu Kesehatan Salewangang Maros.

4. Hasil uji simultan pada variabel kepemimpinan, motivasi kerja, kompetensi menunjukkan pengaruh positif dan signifikan terhadap kinerja pegawai Sekolah Tinggi IImu Kesehatan Salewangang Maros.

5. Dari hasil analisis menunjukkan bahwa 65.6 persen kinerja pegawai pada Sekolah Tinggi IImu Kesehatan Salewangang Maros dipengaruhi oleh ketiga variabel yang diteliti yaitu : kepemimpinan, motivasi kerja, kompetensi.

6. Kepemimpinan merupakan variabel yang paling besar mempengaruhi kinerja, ditunjukkan dengan nilai koefisien standar sebesar 0.588 .

\section{Saran}

1. Pimpinan dalam penerapan gaya kepemimpinan menyesuaikan visi dan misi dari organisasi, setiap perubahan yang akan dilaksanakan oleh pimpinan memperhatikan situasi, kondisi dari pegawai dan terlebih dahulu perlu disosialisasikan sehingga pegawai tidak merasa canggung dengan perubahan yang terjadi, serta penerapan dari setiap kebijakan pimpinan dapat diterima dan dijalankan dengan baik.

2. Pimpinan Sekolah tinggi Ilmu Kesehatan Salewangang Maros diharapkan lebih memperhatikan kompetensi dan motivasi kerja pegawai sehingga pencapaian visi dan misi institusi dapat tercapai.

3. Untuk peneliti selanjutnya yang tertarik dengan penelitian ini untuk melengkapi kekurangan didalam penelitian ini.

\section{DAFTAR PUSTAKA}

Amirullah, A. R. dan K. (2017). Budaya Dan Perilaku Organisasi. Empat Dua.

Azmi, N., \& Serang, S. (2019). Pengaruh Motivasi, Kompetensi dan Lingkungan Kerja Terhadap Kinerja Pegawai. PARADOKS: Jurnal IImu Ekonomi, 2(2), 60-70.

Baard, S. K., Rench, T. A., \& Kozlowski, S. W. J. (2014). Performance adaptation: A theoretical integration and review. Journal of Management, 40(1), 48-99.

Bharata, H. K., \& Putro, S. R. S. (2019). PENGARUH KEPEMIMPINAN BUDAYA ORGANISASI DAN KOMUNIKASI TERHADAP KINERJA KARYAWAN. JOURNAL INFORMATICS, SCIENCE \& TECHNOLOGY, 9(2).

Ghozali, I. (2018). Aplikasi Analisis Multivariate Dengan Program IBM SPSS 25, Edisi Kesembilan. In Semarang: Penerbit Undip.

Hasibuan, M. S. P. (2017). Manajemen Sumber Daya Manusia, Cetakan Ke-21. PT Bumi Aksara. Jakarta, 145.

Lusman. (2017). Pengaruh Motivasi Kerja, Gaya Kepemimpinan dan Kompetensi Terhadap Kepuasan Kerja dan Kinerja Pegawai Pada Kantor Kopertis Wilayah IX Sulawesi. Universitas Muslim Indonesia.

Mangkunegara, A. A. A. P. (2011). Manajemen Sumber Daya Manusia Perusahaan (10th ed.). 
PT. Remaja Rosdakarya.

Mangkunegara, A. A. A. P. (2016). Manajemen sumber daya manusia perusahaan. PT. Remaja Rosdakarya.

Mulyani, S. R. (2019). Pengaruh Kompetensi Pegawai, Penempatan Kerja dan Pengembangan Karir Terhadap Kinerja Pegawai. Psyche 165 Journal, 12(1), 51-63.

Retribusi, P., Tepi, P., Umum, J., Pelayanan, R., Kepelabuhan, R. P., Izin, R., Bangunan, M., Retribusi, D. A. N., \& Trayek, I. (2016). Pengaruh retribusi parkir tepi jalan umum, retribusi pelayanan kesehatan, retribusi pelayanan kepelabuhan, retribusi izin mendirikan bangunan dan retribusi izin trayek terhadap pendapatan asli daerah kabupaten bintan periode 2013-2016. 1-20.

Rivai. Veithzal, Ramli. M, Mutis. Thoby, A. W. (2018). Manajemen Sumber Daya Manusia Untuk Perusahaan (3rd ed.). Rajagrafindo. Depok.

Sedarmayanti, undefined. (2011). Manajemen Sumber Daya Manusia, Reformasi Birokrasi dan Manajemen Pegawai Negeri Sipil (Cetakan Ke-5). 5, 260. https://www.mendeley.com/catalogue/0012619c-d41c-312f-93cc-

f6720a21 fba7/?utm_source=desktop\&utm_medium=1.19.8\&utm_campaign=open_catalog \&userDocumentld=\%7Bb986df2d-3ab5-4d90-9751-2636ff1d06b $\%$ \%7D

Siagian, S. P. (2018). Teori motivasi dan aplikasinya. Rineka Cipta.

Stephen, R. (2006). Perilaku Organisasi (10th ed.). Indeks.

Stephen, R. (2015). Perilaku Organisasi (Ratna Saraswati \& Febriella Sirait (ed.); 16th ed.). Salemba Empat.

Sugiono. (2015). Metode Penelitian Manajemen. Alfa Beta.

Sutrisno. Edy. (2015). Manajemen Sumber Daya Manusia. Kencana Prenada media group.

Wibowo. (2018). Manajemen Kinerja (10th ed.). PT. RajaGrafindo Persada.

Yukl, G. (2015). Kepemimpinan dalam organisasi (edisi 7). In Jakarta: Indeks. 